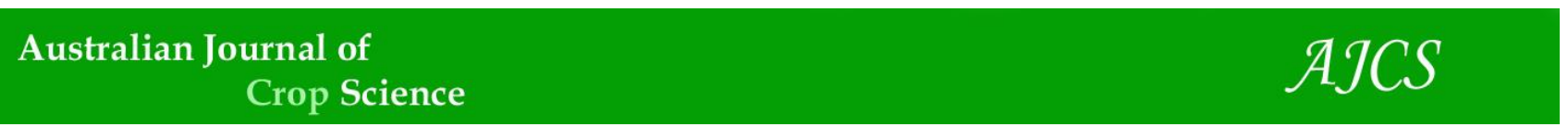

AJCS 14(12):1844-1854 (2020)

ISSN:1835-2707

doi: 10.21475/ajcs.20.14.12.p2515

\title{
Momordica cochinchinensis Spreng (Gac fruit): An abundant source of nutrient, phytochemicals and its pharmacological activities
}

\author{
Priscilla Jayanthi Thavamany ${ }^{1}$, Hong Lim Chew ${ }^{2}$, Sreeramanan $S^{2,3,4}$, Bee Lynn Chew ${ }^{2}$, Ming-Thong Ong ${ }^{*}$ \\ ${ }^{1}$ Institute for Research in Molecular Medicine (INFORMM), Universiti Sains Malaysia, 11800 USM, Penang, Malaysia \\ ${ }^{2}$ School of Biological Sciences, Universiti Sains Malaysia, 11800 USM, Penang, Malaysia \\ ${ }^{3}$ Centre for Chemical Biology, Universiti Sains Malaysia, 11900, Bayan Lepas, Penang, Malaysia \\ ${ }^{4}$ School of Bioprocess Engineering, Universiti Malaysia Perlis (UNIMAP), 02600 Arau, Perlis, Malaysia
}

*Corresponding author: omt@usm.my (also ong.mt1@gmail.com) (Ming-Thong Ong)

\section{Abstract}

Gac fruit (Momordica cochinchinensis Spreng) is an exploitable perennial dioecious fruit found commonly in Southeast Asian countries (SA). Gac fruit has been traditionally used in folk medicine due to its high medicinal and nutritive value. Generally, the aril of the fruit is used as a red colourant for cuisines and supplement for healthier vision. Gac fruit is highly rich in lycopene and $\beta$ carotene, fatty acids, vitamin E, polyphenols like phenolic acids, flavonoids and trypsin inhibitors. These compounds are linked with many important bioactivities such as provitamin A, antioxidant, antimicrobial, antiulcer and anticancer activities. This paper reviews the findings on nutritional properties, phytochemical composition and the biological activities of Gac fruit. The review has also briefly discussed the suitable conditions for the storage and utilisation of the fruit in food, beverage, nutraceutical, pharmaceutical and cosmeceutical industries.

Keywords: Gac fruit; Lycopene; $\beta$-carotene; Phytochemical; Healthcare.

Abbreviations: Southeast Asian countries_SA; mg_miligram; g_gram; FW_fresh weight, $\mu$ g_microgram; $\mathrm{mL}$ _microlitre; MW_molecular weight, TIs_trypsin inhibitors, KDa_kilodaltons; DNA_deoxyribonucleic acid; LLC-PK1_pig kidney epithelial cells; A549, H1264, H1299, Calu-6_ lung cancer cells; $\mu$ mol _ micromole; DPPH_ 2,2-diphenyl-1-picrylhydrazyl; FRAP_ferric reducing

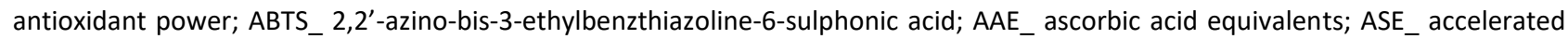
solvent extraction; TE_Trolox; $\mathrm{mm}_{\text {_ }}$ millimeter; MIC_minimmum inhibitory concentration; $\mathrm{MBC}$ _ minimum bactericidal concentration; SP_screw press; SC_supercritical; MCF_Momordica cochinchinensis fruits; kg_kilogram; AE_aril extract; DAPI_4',6diamidino-2-phenylindole; MCF7_breast cancer cell, JNK_c-Jun N-terminal kinases; AKT_protein kinase B; SGC7901 and MKN-28_ gastric cancer cell; PARP_Poly (ADP-ribose) polymerase; ECMS_ethanolic extract of seeds; ECM_extracellular matrix, MMP-2 _ matrix metallopeptidase 2; MMP-9_ Matrix Metallopeptidase 9.

\section{Introduction}

Momordica cochinchinensis Spreng is widespread in Southeast Asian countries (SA), especifically in Vietnam, China, Thailand, India, Indonesia and Malaysia. The fruit is commonly known as Gac, Chinese bitter cucumber and cochinchin gourd (Lim, 2012). This fruit comes from the melon family of Cucurbitaceae inclusive of cucumbers, squash and bitter melon (Kubola et al., 2013). The botanical classification of the fruit is as follows: Plantae (Kingdom); Cucurbitales (Order); Cucurbitaceae (Family); Cucurbitoideae (Subfamily); Momordica (Genus); Momordica cochinchinensis (Species).

Tepurang is the vernacular name given to this fruit in Malaysia and Indonesia. However, names of the fruit vary in different countries (Table 1). The vines of Gac plant can grow up to 6 metre long over a fence. Gac is a perennial dioecious plant with separate male and female plants (Parks et al., 2013). The plant contains leaves of 3-5 palmately lobed, along with white to ivory yellow flowers (Bharathi and John, 2013). Gac plants usually flowers two months after being planted. Female flowers have an unformed fruit forming a bulge at the base whereas male flowers have paled coloured petals that results in an open bloom (Parks et al., 2013). Hand pollination through dusting the pollen on receptive stigma by paint brush is crucial in order to obtain higher fruit setting and yield, especially when the native pollinators are absent (Parks et al., 2013). A Gac plant can yield up to 60 fruits on average in one season (Burke et al., 2005). The fruits become ripe in around 9 to 10 weeks after pollination. The ripe fruit can be harvested when its fruit skin colouration changes from green to yellow, dark orange and finally to red as shown in Figure 1 (Tran et al., 2016). The fruit is hard at harvest but turns soft quickly after harvesting. leading to problems in transportation of the fruit and in its shelf-life (Win et al., 2015). The cultivation of the fruit is mainly from the seeds, branches, and roots (Chuyen et al., 2015).

Gac fruit is value-added due to its importance in health benefits as it contains an exceptional source of lycopene and beta-carotene. The content of lycopene in the fruit has been reported to be five times higher than tomatoes (Aoki et al., 
2002), and that of beta-carotene to be 8 times more than the amount found in carrots (Aoki et al., 2002 ; Kandlakunta et al., 2008). It was also reported that the fruit contained an astounding amount (60 times) of vitamin C compared to that from oranges, and 40 times more zeaxanthin than that found in yellow corn (Aoki et al., 2002). In addition to many recent studies on its traditional uses and biological activities, this review will also focus on the emerging benefits of Gac fruit as therapeutic food.

\section{Gac fruit anatomy}

Typically, Gac fruits are round or ovoid in shape. However, one Gac cultivar grown in India has been reported to have oblong shape (Gopalakrishnan, 2007). The fruit comprises of two main parts, namely mesocarp and endocarp. The mesocarp includes orange/yellow spines that cover the skin, and thick, spongy orange layer called pulp as shown in Figure 2. Fruit spines distribution is ranged from smooth and dense to hard and far apart. The endocarp contains red, soft and sticky arils that cover the black seeds (Vuong, 2000). Each fruit comes with an average of 15 to 20 seeds. The seeds are mainly round, compressed and have a sculptured seed coat covered with red aril as shown in Figure 2. The yellow pulp covers $50 \%$ of the total weight while the aril, the highest amounted carotenoids, forms $10-25 \%$ of the fruit's weight. The skin and seeds are $17 \%$ and $16 \%$ of the fruit's total weight, respectively (Vuong, 2000; Kha et al., 2013; Chuyen et al., 2015). Parks et al. (2013) have shown a correlation between the size of fruit, weight, and portion of aril. The increment of the fruits weight and size would results in higher aril production. However, lighter fruit weight may occur due to loss of water during the storage (Nhung et al., 2010 ; Win et al., 2015).

\section{Traditional uses}

Gac fruit has been consumed in numerous ways amongst various cultures around the world (Tuyen et al., 2013). The pleasant taste of ripened Gac aril is commonly used as a colourant for the preparation of red glutinous rice or xoi Gac (Ishida et al., 2004). This dish is usually served at occasions during new year celebration and weddings in Vietnam (Zheng et al., 2015). On the other hand, the young green fruit can be cooked with chili paste or boiled for food. It is also used to cook curry in Thailand (Kubola and Siriamornpun, 2011). Stir-fried meals and soups reported to be scrumptious with the addition of aril leading to lustrous appearance and distinct flavour of the dish (Chuyen et al., 2015). Xerophthalmia also known as dry eyes and night blindness caused mainly by provitamin A deficiency. It was reported that xerophthalmia could be prevented by the intake of aril oil of Gac fruit as supplement (Chuyen et al., 2015). The seeds of the fruit, called mubiezhi (in Chinese: 木 鳖子), play a vital role in traditional Chinese medicine for treatment of breast cancer (Zheng et al., 2015). It has been shown that the ethyl acetate seed extract inhibited the proliferation of MDA-MB231 cells and induced cell cycle arrest and apoptosis (Zheng et al., 2015). Traditonally, the seeds are used to treat skin problems such as boils, pyodermatitis, ringworm infections, freckles, sebaceous and medical conditions such mastitis, tuberculous cervical lymphadenitis, hemorrhoids and hemangiomas (Zheng et al., 2015). The grounded Gac seeds are used both orally and externally for the treatment of inflammatory scrofula, swelling, and tinea. It can also be used to treat diarrhea and suppurative skin infections such as sore, carbuncles, furuncles and boils in both human and animals (Xiao et al., 2007). In Vietnam, the roots of the plant is believed to promote blood circulation and urination by eliminating the damp heat (Tran et al.,2016). The roots are also used to treat rheumatism, inflammation, swelling of legs and edema (Tuyen et al., 2013, Tran et al., 2016).

\section{Phytochemical composition of Gac fruit}

Gac fruit gained the name "super fruit" or "heaven's fruit" because of its phytonutrients composition like carotenoids, essential fatty acids and other compounds such as fatsoluble vitamins like $\alpha$-tocopherol (vitamin E), phenolic compounds, flavonoids and Vitamin C (Ishida et al., 2004; Kubola and Siriamornpun, 2011). Regular intake of this fruit that contains significant amounts of bioactive components improves basic nutrition and play a significant role in prevention of diseases (Tinrat et al., 2014; Chuyen et al., 2015).

\section{Carotenoids}

Gac fruit holds high levels of carotenoids specially lycopene and $\beta$-carotene in all parts (aril, pulp and peel) up to $500 \mathrm{mg} /$ $100 \mathrm{~g}$ each compared to lycopene rich fruit and vegetable like tomato ( $3.1 \mathrm{mg} / 100 \mathrm{~g}$ ), watermelon ( $4.1 \mathrm{mg} / 100 \mathrm{~g}$ ) and pink grapefruit (3.36 mg / $100 \mathrm{~g}$ ) (Aoki et al., 2002). The discrepant results of total carotenoid content (lycopene and $\beta$-carotene) in aril contents was determined as $48.1 \mathrm{mg} /$ $100 \mathrm{~g}$ fresh weight (FW) (Aoki et al., 2002) as indicated in Table 2. Further studies on Gac fruit showed varied results of total carotenoid content reported such as $294.5 \mathrm{mg} / 100 \mathrm{~g}$ FW (Ishida et al., 2004), $49.7 \mathrm{mg} / 100 \mathrm{~g} \mathrm{FW}$ (Vuong et al., 2006), and $410.7 \mathrm{mg} /$ 100g FW (Nhung et al., 2010), 1502 $\mathrm{mg} / 100 \mathrm{~g}$ (Kubola and Siriamornpun 2011), and $78 \mathrm{mg} / 100 \mathrm{~g}$ FW (Tran et al., 2016). The total carotenoid contents showed highest in aril >pulp > peel (Aoki et al., 2002). In one study investigated by Nhung et al. (2010), the total carotenoid content showed highest in ripe fruits compared to green or medium ripe fruit. Thus, the fruit maturity is one of factors to be considered to obtain highest yield of carotenoids. Apart from that, transportation and storage conditions above $-20^{\circ} \mathrm{C}$ may cause isomerization and degradation of carotenoids as most are sensitive to heat and light (Vuong et al., 2006). Gac fruit also contains other carotenoids such as lutein, zeaxanthin, and $\beta$-cryptoxanthin Lutein and zeaxanthin are derived from xantophylls which has been extensively utilized to treat eye-related diseases such as cataracts (Vuong and King, 2003, Giordano and Quadro, 2018). Although lutein is present in all parts of the fruit, its content in the peel and pulp were found to be in higher concentrations at 1248 and $144.8 \mathrm{mg} / 100 \mathrm{~g} \mathrm{FW}$, respectively. The analysis of Gac fruit conducted by Aoki et al. (2002) showed the presence of $0.9 \mathrm{mg} / 100 \mathrm{~g} \mathrm{FW}$ zeaxanthin and $0.2 \mathrm{mg} / 100 \mathrm{~g} \mathrm{FW} \beta$-cryptoxanthin in seed membrane (Gac aril), whereas $0.16 \mathrm{mg} / 100 \mathrm{~g}$ zeaxanthin and $0.35 \mathrm{mg} / 100 \mathrm{~g} \mathrm{FW} \beta$ - cryptoxanthin were found in fruit meat (Gac pulp) (Aoki et al., 2002). Hence, it can be deduced that apart from the aril, the yellow pulp and skin form a huge potential source of carotenoids.

\section{Vitamins}

The mean concentration of Vitamin $E$ ( $\alpha$-tocopherol) found in Gac aril was $7.6 \mathrm{mg} / 100 \mathrm{~g}$ of fresh weight, higher when compared to Gac pulp or even other Momordica genus such 
as M.Charantia (bitter melon) (Vuong et al., 2006). In a later study, the $\alpha$-tocopherol content in peel, pulp and seed membrane extract were 1.46, 1.53 and $1.30 \mathrm{mg} / 100 \mathrm{~g}$, respectively (Reungpatthanaphong et al., 2018). Consuming vitamin $\mathrm{E}$ rich Gac fruit significantly contribute to the daily intake of vitamin $E$ ( $15 \mathrm{mg} /$ day) as recommended (Vuong et., 2006 ; Institute of Medicine, 2000). Apart from that, vitamin $E$ also plays an important role in preventing the polyunsaturated oil in the fruit from oxidation (Vuong and King, 2003). Water soluble Vitamin C (ascorbic acid) content was detected in Gac fruit at $42.57 \mathrm{mg} / 100$ under wild growing condition in India (Sarmah et al., 2018). The investigation suggests that presence of vitamin C correlated to its antioxidant activity. Thus, these fruits can be consumed as dietary food for its high nutraceutical activity.

\section{Polyphenolics and flavonoids}

Both phenolic and flavonoids compounds are widely distributed in many plants and have gained much attention as primary antioxidants through their free-radical scavenging abilities by reacting with hydroxyl, superoxide anion and lipid peroxy radicals (Chandra et al., 2014). They also protect DNA from oxidative damage, inhibit growth of tumor cells and posses anti-inflammatory, anticancer and antimicrobial properties (Lee et al., 2017). The total phenolic content (TPC) values have been reported as: aril > peel > pulp > seed while the total flavonoid content (TFC) were peel > aril> pulp $>$ seed (Kubola and Siriamornpun 2011). Kubola and and Siriamornpun (2011) reported a positive correlation for the antioxidant activity and the contents of total flavonoids phenolics of Gac fruit. In another study by Tinrat et al. (2014), they obtained highest TPC in the flesh acetone extract (41.6 $\pm 0.246 \mathrm{mg} \mathrm{GAE} / 100 \mathrm{~g} \mathrm{FW})$ and aril's methanolic extract $(73.7 \pm 0.00 \mathrm{mg} \mathrm{RE} / 100 \mathrm{~g} \mathrm{FW}$ ) (Tinrat 2014). The total antioxidant activities of Gac fruit accordingly to the following order of aril> peel > flesh.

\section{Fatty acids}

Gac fruit contains mixture of unsaturated, saturated, polyand mono-unsaturated fatty acids. Vuong et al. (2002) reported seventy percent of the total fatty acids from 102 $\mathrm{mg} / \mathrm{g}$ fresh weight comprised of unsaturated and $50 \%$ were polyunsaturated. The fatty acid composition of the Gac aril is listed in Table 3. Major fatty acids present in aril are oleic, palmitic and linoleic as shown in Table 3. On the other hand, stearic, linoleic, oleic and palmitic are the main fatty acids in Gac seeds (Ishida et al., 2004). Percentage reported by other authors are also listed for comparison (Kha et al., 2014, Bruno et al., 2018).

Interestingly, the study conducted by Bruno et al. (2018) showed that Gac fuit contained higher concentration of oleic acid, $44.5 \%$ of total fatty acids, when compared to tomato and watermelon at $2.5 \%$ and $20.7 \%$ respectively. Hence, it can be used as a source of oleic acid in addition to other sources such as soya, palm and coconut (Vuong and Kind 2003). These fatty acids from aril play a vital role in the uptake of fat-soluble nutrients like carotenoids through lowfat diet (Vuong et al., 2002 ; Kuhnlein, 2004 ; MullerMaatsch et al., 2017). It has been shown that Vietnamese households use Gac fruit oil as a substitution for pork fat (Vuong and King, 2003). The consumption of Gac fruit oil (2 $\mathrm{mL} /$ day) increases the intake of $\beta$-carotene and essential fatty acids as well as reduces the intake of saturated fatty acids (Vuong and King, 2003). Several authors reported intake of saturated fatty acids increases the risk of contracting cardiovascular disease. However, usage of Gac fruit oil containing, mono- or poly- unsaturated fatty acids over coconut oil and fat of animal origin may prevent from long-term effect on health (Rodriguez Levya et al., 2010 ; Poudyal et al., 2011). Thus, the composition of fatty acids and high carotenoids in Gac oil suggests that Gac fruit is a fruit with high nutritional value (Vuong and King, 2003).

\section{Trypsin inhibitors}

Trypsin inbitors (Tis) are low molecular weight peptides and inhibits the hydrolase activity of serine proteases (Le et al., 2018). The seeds of Gac fruit are known to contain trypsin inhibitors also known as Momordica cochinchinensis trypsin inhibitors (MCoTIs) (Liu et al., 2012). MCoTIs contains 28-34 amino acid residues, 6 cysteine residues which forms 3 disulfide bonds structurally (Le et al., 2018). A total of nine tryspin inhibitors have been isolated and sequenced from the seeds of Gac fruit. Huang et al. (1999) isolated a trypsin inhibitor from Gac seed with molecular weight (MW) of $3.479 \mathrm{kDa}$, belonging to the squash family inhibitors. Furthermore, three other trypsin inhibitors (TIs) were segregated from the seeds of the squash Momordica cochinchinensis (Hernandez et al., 2000).

In addition, five trypsin inhibitors with MW of 5.1, 4.8, 4.4, 4.1, and 3.9 kDa were reported to be present in Gac seeds (Wong et al., 2004). Due to their low molecular weight, they are compact and very stable (Hernandez et al., 2000). This enables them to penetrate into cells. In the study conducted by Le et al. (2018) was highlighted on protease inhibitors which have various biochemical functions such as acting as anticancer agents by inhibiting the growth of two melanoma cells (MM418C1 and D24) compared to control.

\section{Others saponins}

Several studies on ethanolic extract of Gac seed have reported that chemical compounds such as saponins from the seed have renoprotective effects against cisplatininduced damage to LLC-PK1 pig kidney epithelial cells in vitro via blocking of mitogen-activated protein kinase (MAPKs) signaling cascade (Jung et al., 2016). The three major saponins that have been isolated are tabulated in Table 4 as gysogenin (compound 1), quillaic acid (compound 2) and gypsoside (compound 3). In another study conducted by $\mathrm{Yu}$ et al. (2017) on four lung cancer cell lines, namely A549, H1264, H1299, Calu-6 and primary lung endothelial cells from human confirmed that cell proliferation was inhibited for all the cell lines with two major saponins identified previously as gysogenin and quillaic acid (Yu et al., 2017).

\section{Pharmacological activities of Gac fruit}

New developments associated with Gac fruit have led to keen interest in many biological activities including the synthesis of provitamin $A$ in the fruit and antioxidant properties of the fruit (Vuong et al., 2002, Barathi et al., 2014). Moreover, the anticancer and antimicrobial properties of the fruit have also been extensively investigated (Liu et al., 2012, Innum 2013, Tinrat and Asna 2016).

\section{Provitamin A activity}

Momordica cochinchinensis is a reservoir for vitamin A due to the presence of $\beta$-carotene, which provide vitamin $A$ after enzymatic cleavage. $\beta$-carotene is converted to retinal and 
Table 1. Vernacular names of Momordica cochinchinensis based on the different Asian countries. Adopted from (Lim, 2012).

\begin{tabular}{ll}
\hline Countries & Vernacular names \\
\hline Bangladesh & Kakrol \\
China & Da Ye Mu Bie Zi, Mu Bie, Mù-Biē Guŏ, Mu Bie Zi, Teng Tong, Tu Mu Bie \\
India & Bhat Kerala, Golkara, Kakrol, Gangerua, Gulkakra, Kakur, Kakrol, Kantola, Kathaamla \\
Indonesia & Pupia, Torobok, Toropu \\
Laos & Khaawz \\
Malaysia & Teruah, Terupang \\
Philippines & Tabog-Ok, Tabog- Uak \\
Thailand & Bai- Khai- Du, Fak-khao, Phak-Khao \\
& Khika-Khrua Yawd-Fak-Kao \\
Vietnam & Red Gac, Mộc Miết Tử \\
Cambodia & Makkao \\
\hline
\end{tabular}

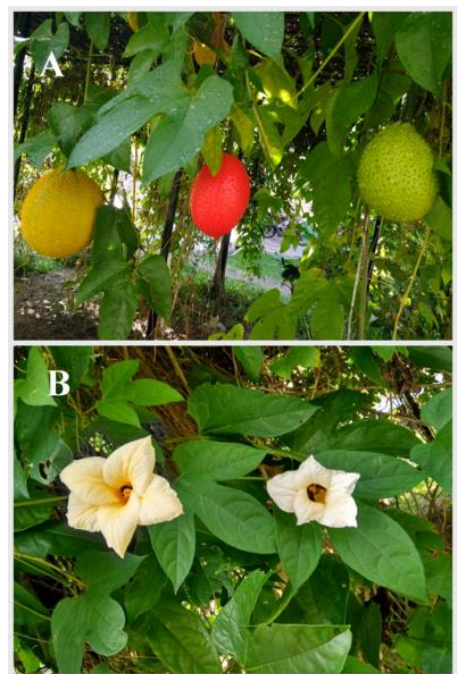

Fig 1. (A) Leaves and fruits of Gac plant; (B) Female (right) and male (left) flowers of Gac plant.

Table 2. Carotenoid contents of Gac aril [mg/ $100 \mathrm{~g}$ FW].

\begin{tabular}{cccl}
\hline$\beta$ - carotene & Lycopene & Total carotenoids & References \\
\hline 10.1 & 38.0 & 48.1 & Aoki et al., 2002 \\
71.8 & 222.7 & 294.5 & Ishida et al., 2004 \\
8.3 & 40.8 & 49.7 & Vuong et al., 2006 \\
37.9 & 372.8 & 410.7 & Nhung et al., 2010 \\
800 & 702 & 1502 & Kubola and Siriamornpun 2011 \\
33 & 45 & 78 & Tran et al., 2016 \\
\hline
\end{tabular}

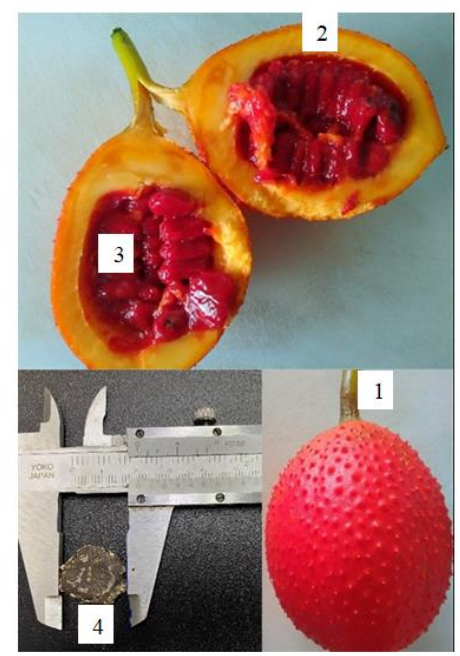

Fig 2. Anatomical parts of Gac fruit (1. Peel with spines, 2. Pulp, 3. Aril, 4. Seed). 
Table 3. Composition of fatty acids in aril of Gac fruit (\% total fatty acid)

\begin{tabular}{|c|c|c|c|c|c|c|}
\hline & & & \\
\hline & & (Vuong et al., 2002) & (Ishida et al., 2004) & ( Mai et al., 2013) & Kha et al., 2014) & (Bruno et al., 2018) \\
\hline \multirow[t]{4}{*}{ Saturated Fatty Acids (SUFAs) } & $\begin{array}{l}\text { Palmitic } \\
(16: 0)\end{array}$ & 22.04 & 29.2 & 17.31 & 24.76 & 30.1 \\
\hline & $\begin{array}{l}\text { Stearic } \\
(18: 0) \\
\end{array}$ & 7.20 & 7.7 & 7.45 & 6.72 & 5.1 \\
\hline & $\begin{array}{l}\text { Myristic } \\
(14: 0)\end{array}$ & 0.89 & 0.5 & 0.22 & 0.42 & 0.8 \\
\hline & $\begin{array}{l}\text { Arachidic } \\
(20: 0)\end{array}$ & 0.40 & 0.5 & 0.32 & - & - \\
\hline \multirow[t]{2}{*}{$\begin{array}{l}\text { Monounsaturated } \\
\text { Fatty Acids MUFAs) }\end{array}$} & $\begin{array}{l}\text { Oleic } \\
\left(18: 1 \Delta^{9}\right) \\
\end{array}$ & 34.76 & 32.3 & 59.50 & 49.18 & 44.5 \\
\hline & $\begin{array}{l}\text { Palmitoleic } \\
\left(16: 1 \Delta^{9}\right)\end{array}$ & 0.27 & 0.3 & 0.18 & 0.43 & - \\
\hline \multirow{2}{*}{$\begin{array}{l}\text { Polyunsaturated } \\
\text { (PUFAs) }\end{array}$} & $\left(18: 2 \Delta^{9,12}\right)$ & 32.06 & 28.1 & 13.98 & 17.65 & 19.6 \\
\hline & $\begin{array}{l}\alpha \text {-linoleic } \\
\left(18: 3 \Delta^{9,12,15}\right)\end{array}$ & 2.18 & 0.5 & 0.52 & 0.84 & - \\
\hline
\end{tabular}

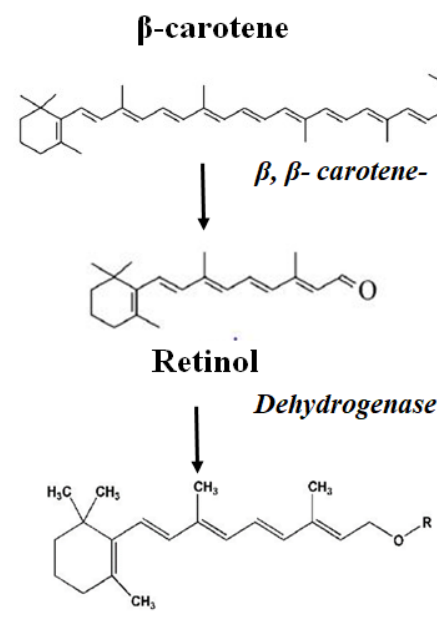

Retinal(Vitamin A)

Fig 3. Chemical structure of $\beta$ - carotene and its derivatives. 
Table 4. Saponins in Gac seeds.

Gypsogenin (1)

3-O- $\beta$-Dgalactopyranosyl $(1 \rightarrow 2)[\alpha-L-$-rhamnopyranosyl $(1 \rightarrow 3)] \beta$-D-glucuronopyranoside

Quillaic acid (2)

3-O- $\beta$-Dgalactopyranosyl $(1 \rightarrow 2)[\alpha$-L-rhamnopyranosyl $(1 \rightarrow 3)] \beta$-D-glucuronopyranoside

Jung et al., 2016

Momordica Saponin I

(Gypsoside) (3)

3-O- $\beta$-Dgalactopyranosyl(1->2)[ $\alpha$-L-rhamnopyranosyl(1>3)]- $\beta$-Dglucuronopyranosido-280- $\beta$ -

D-xylopyranosyl(1>3)- $\beta$-Dglucopyranosyl(1->3)-[ $\beta D$-xylopyranosyl(1->4)]- $\alpha-L-$

rhamnopyranosyl(1->2) $\beta$-Dfucopyranosylgypsogenin
rento

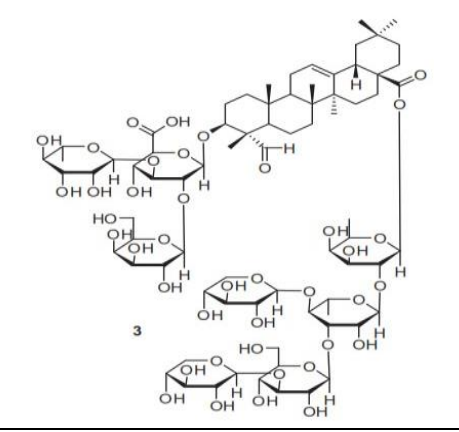

Jung et al., 2016

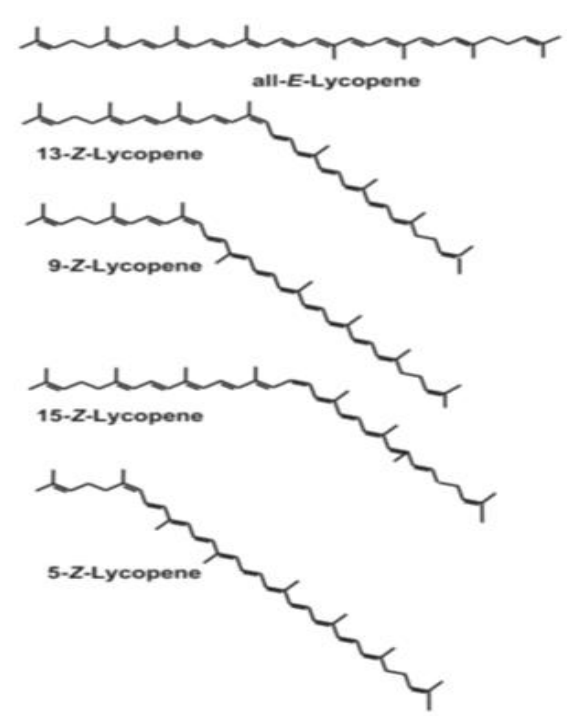

Fig 4. Geometric isomers of lycopene (Rodriguez-Amaya, 2015). 
Table 5. Antioxidant activity of various extract from different parts of Gac fruits.

\begin{tabular}{|c|c|c|c|}
\hline Extracts & Antioxidant Assay & Results & References \\
\hline \multirow{9}{*}{$\begin{array}{l}\text { Extracts obtained by accelerated solvent } \\
\text { extraction (ASE) }\end{array}$} & DPPH ABTS & Peel: $\mathrm{EC}_{50}=11.78 \pm 0.45 \mathrm{mg} / \mathrm{ml}$ & (Reungpatthanaphong et al., 2018) \\
\hline & FRAP & ABTS: $\mathrm{EC}_{50}=81.27 \pm 1.26 \mathrm{mg} / \mathrm{ml}$ & \\
\hline & & $\mathrm{FRAP}=252.06 \pm 31.68 \mu \mathrm{m}$ & \\
\hline & & Pulp: $\mathrm{EC}_{50}=8.65 \pm 0.15 \mathrm{mg} / \mathrm{ml}$ & \\
\hline & & ABTS: $\mathrm{EC}_{50}=82.48 \pm 4.04 \mathrm{mg} / \mathrm{ml}$ & \\
\hline & & $\mathrm{FRAP}=112.11 \pm 5.3 \mu \mathrm{m}$ & \\
\hline & & Seed: $\mathrm{EC}_{50}=71.25 \pm 1.22 \mathrm{mg} / \mathrm{ml}$ & \\
\hline & & ABTS: $\mathrm{EC}_{50}=77.44 \pm 2.65 \mathrm{mg} / \mathrm{ml}$ & \\
\hline & & $\mathrm{FRAP}=57.06 \pm 13.88 \mu \mathrm{m}$ & \\
\hline \multirow[t]{6}{*}{ Ethanolic extract (peel, pulp and aril) } & DPPH\& FRAP & Peel= $4.56 \mathrm{mg} \mathrm{AAE} / \mathrm{g} \mathrm{FW}$ & (Tinrat et al., 2014) \\
\hline & & $\mathrm{FRAP}=0.012 \mathrm{mg} \mathrm{AAE} / \mathrm{g} \mathrm{FW}$ & \\
\hline & & Pulp $=2.41 \mathrm{mg} \mathrm{AAE} / \mathrm{g} F W$ & \\
\hline & & $\mathrm{FRAP}=0.012 \mathrm{mg} \mathrm{AAE} / \mathrm{g} \mathrm{FW}$ & \\
\hline & & Aril= $4.87 \mathrm{mg} \mathrm{AAE} / \mathrm{g} \mathrm{FW}$ & \\
\hline & & $\mathrm{FRAP}=0.016 \mathrm{mg} \mathrm{AAE} / \mathrm{g} \mathrm{FW}$ & \\
\hline \multirow{8}{*}{$\begin{array}{l}\text { Ethanolic extracts of Gac peel, pulp, aril and } \\
\text { seed }\end{array}$} & DPPH\& FRAP & Peel: $I_{50}=2.56 \mathrm{mg} \mathrm{g}^{-1}$ & (Kubola and Siriamornpun, 2011) \\
\hline & & FRAP: $472 \mu \mathrm{mol} \mathrm{FeSO}_{4} \mathrm{~g}^{-1}$ & \\
\hline & & Pulp: $I C_{50}=2.53 \mathrm{mg} \mathrm{g}^{-1}$ & \\
\hline & & FRAP: $466 \mu \mathrm{mol} \mathrm{FeSO}_{4} \mathrm{~g}^{-1}$ & \\
\hline & & Aril: $I C_{50}=3.66 \mathrm{mg} \mathrm{g}^{-1}$ & \\
\hline & & FRAP: $531 \mu \mathrm{mol} \mathrm{FeSO}{ }_{4} \mathrm{~g}^{-1}$ & \\
\hline & & Seed $: I_{50}=6.66 \mathrm{mg} \mathrm{g}^{-1}$ & \\
\hline & & FRAP: $36.3 \mu \mathrm{mol} \mathrm{FeSO}{ }_{4} \mathrm{~g}^{-1}$ & \\
\hline \multirow[t]{2}{*}{ Methanol extract of immature Gac fruit (green) } & DPPH FRAP & $45.1 \mathrm{mg} \mathrm{AAE} / 100 \mathrm{~g}$ & (Bharathi et al., 2014) \\
\hline & & $5.9 \mathrm{mg} \mathrm{AEAC/} 100 \mathrm{~g}$ & \\
\hline Gac aril Lycopene in cis-isomers & ABTS & 3.7 $\mu \mathrm{mol} \mathrm{TE}$ & (Phan-Thi and Wache, 2014) \\
\hline Spray dried Gac aril powder & ABTS & $1.4 \mathrm{~mm} \mathrm{TE} \mathrm{g}^{-1}$ & (Kha et al., 2010) \\
\hline \multirow[t]{2}{*}{ Vacuum dried Gac aril } & ABTS & $162 \mathrm{~mm} \mathrm{TE} \mathrm{g}^{-1} \mathrm{DW}$ & (Mai et al., 2013a; Mai et al., 2013b) \\
\hline & $\mathrm{DPPH}$ & $124 \mathrm{~mm} \mathrm{TE} \mathrm{g}^{-1} \mathrm{DW}$ & \\
\hline
\end{tabular}

retinol by $\beta$-carotene $15,15^{\prime}$ monooxygenase enzyme (BCMO1 gene) (Figure 3). This enzyme not only plays an important role in converting vitamin $A$ but also decreases the amount of $\beta$-carotene by converting this latter into retinal via feedback loop when higher level of retinoic acid is detected in the body (Seino et al., 2008).

An in vivo (human) study among 185 Vietnamese preschoolers conducted by Vuong et al. (2002), confirms the $\beta$-carotene in Gac fruit is highly bioavailable. The author suggests that the readily bioavailable $\beta$-carotene in Gac is presumably due to its fatty acids (Vuong et al., 2002). The existence of fatty acids stimulates the intestinal uptake of $\beta$ carotene in the body by forming micelle, which can be easily absorbed in the intestines by passive diffusion through the border of enterocytes (Yeum and Rusell, 2002 ; Failla et al., 2008; Reboul, 2019). Hence, it can be concluded that Gac fruit has highly potential and bioaccessible source of provitamin A.

\section{Antioxidant activity}

The diphenyl-picrylhydrazyl (DPPH) radical scavenging, ferric reducing antioxidant power (FRAP), and $2^{\prime} 2^{\prime}$-azino-bis 3ethylbenzothiazoline-6-sulphonic acid (ABTS) were used in determining various antioxidant activities. Numerous studies were conducted on the antioxidant properties of Gac fruit (Table 5). Investigation on the aril, peel, pulp and seed showed that the antioxidant capacity was highest in aril fraction. A decrease was reported in the antioxidant capacity from immature to ripe stage for pulp and peel, whereas the seed increased from mature to ripe stage. The decrease observed in the antioxidant capacity in DPPH and FRAP were correlated to the decrease in the total phenolic content and total flavonoid levels during the fruit development stage (Kubola and Siriamornpun, 2011). Bharathi et al. (2014) reported that immature Gac fruit ( 25 days after pollination) contained 45.06 and $5.84 \mathrm{mg}$ AAE / $100 \mathrm{~g}$ ascorbic acid for DPPH and FRAP, respectively.
In another study, Tinrat et al. (2014) reported that the ripe ethanolic aril extract had the highest antioxidant activities at 4.87 and $0.016 \mathrm{mg}$ ascorbic acid equivalents in FRAP and $\mathrm{DPPH}$ as compared to peel and pulp, respectively. Thus, it can be concluded from these studies that the antioxidant capacity of Gac fruit is influenced by its fraction parts and maturation. Several authors suggested suitable drying method with optimal drying temperature could improve antioxidant properties from the aril (Kha et al., 2010 ; Mai et al., $2013 \mathrm{a}, \mathrm{b})$. The $\mathrm{Gac}$ aril powder prepared in a concentration ranging from $10-20 \%$ of maltodextrin using spray drying method and increasing drying temperature from 120 to 200 ㅇ C showed significant loss of antioxidant activity from 0.14 to $0.08 \mathrm{mmol}$ Trolox (TE)/ g of powder components (Kha et al., 2010). These effects in the antioxidant activity may be due to the thermal treatment that destroys the antioxidant components (Kha et al., 2010). In 2013, Mai et al. (2013) highlighted that moisture content (15-18\%) of Gac aril was retained by semi-drying via vacuum dryer at optimal temperature of $60 \circ \mathrm{C}$ to improve the retention of the carotenoids. This method has helped to retain up between 81 to $87 \%$ of the total antioxidant from the fresh Gac aril (Mai et al., 2013a,b).

Isomerization by heat treatment made Gac's lycopene more antioxidant. The all-trans-form lycopene isomerized to the 13- and 9-cis isomers at $80^{\circ} \mathrm{C}$ (Figure 4). The increase of this cis-isomers results in higher antioxidant activity in the extract related to higher solubility compared to transisomers (Phan-Thi and Wache, 2014). However, caution must also be taken as isomerization is the first step of degradation since cis -isomers are less stable and easily cleaved than trans-isomers (Phan-Thi and Wache, 2014). The antioxidant values and carotenoid level for the Gac fruit were higher when extracted using ultrasonic-assisted extraction (UAE) at $75^{\circ} \mathrm{C}$ for $15 \mathrm{~min}$ (Natnoi \& Pirak, 2019). UAE extraction changed the lycopene isomerization from alltrans to cis-isomers giving rise to high antioxidant activity without degradation (Natnoi \& Pirak, 2019). 


\section{Antimicrobial activity}

Antibiotic resistance has emerged as global problem and possesses a threat to human health. This situation can be overcomed with the presence of antimicrobials (secondary metabolites) in plants. These antimicrobials can inhibit the growth of microorganisms effectively with minimum side effects and low cost (Putta et al., 2014). Gac fruit has abundance of bioactive phytochemicals, particularly carotenoids like lycopene, $\beta$-carotene, lutein, phenolic compounds that may exert antimicrobial capacity (Putta et al., 2014). The antimicrobial activity of Gac aril and pulp extracts extracted with aqueous, 95\% ethanol and ether was investigated against different strains of Gram positive and negative bacteria. The ethanolic pulp extract showed the highest antimicrobial activity against Micrococcus luteus $745(20 \mathrm{~mm})$ and $884(15.5 \mathrm{~mm})$.

Nevertheless, the ether extract using both pulp and aril showed no antimicrobial activity (Innum , 2013). In another study, the ethanolic extract from peel and pulp showed significant inhibitory effects with minimum inhibitory concentration (MIC) value of $1.562 \mathrm{mg} / \mathrm{mL}$ for E.coli while the aril extract inhibited P.euroginosa with MIC value of $3.125 \mathrm{mg} / \mathrm{mL}$ (Tinrat et al., 2014). These results prove that the ethanolic extract showed antimicrobial activity against both Gram positive and negative bacteria. Tinrat and Asna (2016) highlighted that crude aril oil obtained through screw press and supercritical $\mathrm{CO}_{2}$ fluid technique extraction showed prominent inhibition against Gram positive and negative bacteria. MIC and $\mathrm{MBC}$ values of crude extracts and oils varies between 0.78 and $400.0 \mathrm{mg} / \mathrm{mL}$ (Tinrat and Asna, 2016).

\section{Anti-ulcer}

In the findings of Kang et al. (2010) reported that the treatment with Gac seed (SK-MS10) hasten the healing of acetic acid induced gastric ulcers by enhancing angiogenesis and the expression of angiogenic factor,VEGF. Gac seed extract showed promising anti-gastritis effect in ethanoland diclofenac-induced gastritis when compared to standard rebamipide treatment (Jung et al., 2013). The results obtained suggested that Momordica saponin 1 from seed could be used as an active biomarker compound. Moreover, the seed extract demonstrated comparable wound healing effect to positive control drug, CGS-21680 (Jung et al., 2013a).

In another study, anti-ulcer properties of methanolic extract of Momordica cochinchinensis fruits (MCF) was tested on ethanol-induced ulcer models in experimental rats at 50 and $300 \mathrm{mg} / \mathrm{kg}$ and pylorus ligation (Sowjanya et al., 2015). Both these concentrations showed a significant reduction in gastric volume, free acidity, total acidity based on the ulcer index as compared to control (Sowjanya et al., 2015). Thus, it can be concluded that the extract possesses anti-ulcerogenic properties as well as ulcer healing properties, which could be due to its anti-secretory activity (Sowjanya et al., 2015).

\section{Anti-inflammatory}

The Gac seed contains rich source of triterpenoids and saponins. The triterpenoidal saponins, among the isolated momordica saponin 1 inhibited the production of nitric oxide (NO) production and transcriptional activation of inhibitory genes further suppress the activation of inflammatory signaling proteins linked to the activation of NFKB (Yu et al., 2017). Another saponin, quillaic acid glycoside, demonstrated anti-inflammatory effects in lipopolysacharride (LPS)- activated RAW 264.7 cells by blocking the expression of nitric oxide (NO), IL-6 and downregulating iNos expression and cyclooxygenase (COX)-2 via NF-kB pathway (Jung et al., 2013b). Wang et al. (2019) investigated five new lignans mubiesins and twenty-seven known compounds (including lignans, sterols) for cytotoxic and anti-inflammatory activities. The results indicated that seventeen compounds could inhibit the release of $\mathrm{NO}$ and TNF- $\alpha$ in LPS-induced RAW 264. 7 cells. Thus, Gac seed could be a promising tool in treating inflammatory disease.

\section{Anti-cancer activity}

Herbs have been broadly used as a substitute remedy for cancer treatment (Shukla and George, 2011). The presence of high carotenoids such as lycopene, $\beta$-carotene and phenolic compounds in the Gac fruit has drawn numerous studies to be conducted on anticancer activity as these compounds are being extensively studied for their abilities to inhibit or supress cancer related oxygen radicals based on various mechanisms via in vitro and in vivo conditions.

The gac seed ethanol extracts inhibited the proliferation of human SGC7901 and MKN-28 gastric cancer cells (Liu et al., 2012). In addition, the extract induces apoptosis by increasing the caspase 3, 9 and 8 activities through poly (ADP-ribose) polymerase (PARP) and p53 signalling pathways. Likewise, Shen et al. (2015) found that Gac seed suppressed the proliferation of human lung cancer cell line, A549 by inducing apoptosis via p53 activation and inactivation of PI-3K/ AKT signaling pathways. The migration and invasion was inhibited by seed extracts via reduction in the expression of STAT-3, MMP-2 and increased the expression of E-cadherin. However, no effects were seen in the expression of VEGF (Shen et al., 2015).

Similarly, Zheng et al. (2014) discovered strong inhibitory effects of seed extract against human breast cancer ZR-7530 cell line. The enzymatic activity of MMP-2 and MMP-9 were repressed by seed extract leading to inhibition of metastasis in breast cancer treatment Gac seed showed good anticancer potential against two melanoma cell lines (MM418C1 and D24), effect of which was higly associated with trypsin inbitors extracted efficiently with water (Le et al., 2018). In a recent study, few lignans namely Mubiesins showed cytotoxicity against growth of tumor cell lines Hepg2, B16, SGC-790 with IC50 value less than $10 \mu \mathrm{M}$ (Wang et al., 2019).

Gac aril water extract inhibited the proliferation of colon 2620 and HepG2 cell lines transplanted in Balb/c mice via inducing necrosis rather than apoptosis. This was evidenced by the downregulation of cyclin A, Cdk2, p27waf1/ Kip 1 (Tein et al., 2005). It has also been shown that a protein with $35 \mathrm{kDa}$ molecular weight, highly water soluble is responsible for the antitumor activity. In addition, lycopene-enriched aril extract (AE) demonstrated cytotoxicity and antiestrogenicity on human MCF-7 breast cancer cell line with cell shrinkage and chromatin condensation,leading to intrinsic and extrinsic apoptosis pathways (Petchsak and Sripanidkulchai, 2015). Cytotoxicity with 60 and 70\% mortality on breast and melanoma cells using aril's water extract was obtained and it was suggested that the reduction in cell viability could be through necrotic phase of apoptotic pathways (Wimalasiri et al., 2016). Abdulqader et al. (2018) demonstrated a remarkable effect of Gac fruit 
(peel, pulp, seed and aril) on human retinal pigment epithelial cells ARPE-19 cell viability. They found that the introduction of Gac fruit extracts to ARPE19 cells in high glucose condition $(30 \mathrm{mmol} / \mathrm{L}$ ) led to inhibition of cell viability which was evidenced by morphological changes of the cells. The fruit showed decreased level of reactive oxygen (ROS) and vascular endothelilal growth factor (VEGF) secretions, and increases the amount of pigment epitheliumderived factor (PEDF) levels which is a pre-requiresitive for angiogenesis process.

\section{Other properties of Gac fruit}

Reductions of sperm concentration and seminiferous tubule diameters are the adverse effects of valproic acid (VPA) treatment. The aril water extract showed protective effect against adverse male reproductive parameters and testicular damage induced by VPA with an increase in sperm concentration and seminiferouls tubule diameters. The extract also protects the decrease of the weights of the epididymis and seminal vesicle (Sukhorum et al., 2016).

The Gac seed extract showed neutrotrophic effects by mimicking the effects of NGF through early pERK signalling pathways and their morphological changes in structural protein is associated with neutrite branching and outgrowth (Mazio et al., 2015). It was reported that a protein with 17 $\mathrm{kDa}$ obtained from the Gac seed extract induced the neutrite outgrowth in PC-12 cells (Mazio et al., 2018). A clinical study on Gac-containing antiwrinkle cream formulation showed that the cream effectively worked to increase the cutaneous hydration (moisture) and smoothness, also reduced skin wrinkles (Leevutinum et al., 2015). In addition, the presence of carotenoids (lycopene, $\beta$-carotene) in Gac fruit contributes to substantial free radical scavenging activity evident in DPPH and ABTS assay (Leevutinun et al., 2015). Gac fruit is also safe for human consumption making it an effective antiwrinkle cream product.

\section{Storage of Gac fruit}

Long term storage management requires a intensive study in changes in postharvest quality of Gac fruit and shelf life in order to minimize the losses in commercialization of Gac fruit. Proper maturity index, growing and optimized storage conditions plays a great impact on the nutritional value of the fruit. Gac fruit harvested prior to full maturity (fully ripe) can increase their nutritional qualities, lycopene and $\beta$ carotene contents in aril (Kubola and Siriamornpun, 2011, Tran et al., 2017). Gac fruit at fully ripe stage reported the highest amount of carotenoids ( 3.852 and $0.409 \mathrm{mg} / \mathrm{g}$ aril FW) for lycopene and $\beta$-carotene which decreases after 14 days of storage (Nhung et al., 2010). Thus, these authors concluded that fruit firmness and maturity index are important factors for quality management (Nhung et al. 2010). The fruit stored at low temperature $\left(10-13^{\circ} \mathrm{C}\right)$ lasted for 30 days when compared to that at high temperature $\left(25^{\circ} \mathrm{C}\right)$ (Win et al., 2015). This latter only lasted half shelf life of the fruits kept at low temperature. Thus, it was concluded that storage at low temperatures was the best way to maintain the quality of the fruit and its products. However, fruit exhibited chilling injury symptoms both internally and externally at $4^{\circ} \mathrm{C}$ (Win et al., 2015).

Gac powder stored in vacuum storage below $25^{\circ} \mathrm{C}$ retained the best quality of total carotenoids over 4 months after pretreatment and dehydration with various drying process (Tran et al., 2008). The addition of antioxidant agents during drying significantly prevented the loss of total carotenoid in the powder due to precipititation of $\beta$-carotene at $5^{\circ} \mathrm{C}$ ( Minh and Dao, 2013). Gac aril powder supplemented with Vitamin $C$ at 2000ppm and mixing carrier maintained $70 \%$ carotene content for three months at $10^{\circ} \mathrm{C}$ or five months at $5^{\circ} \mathrm{C}$ in the absence of oxygen and light (Minh and Dao et al., 2013). Further studies on storage and preservation of carotenoids in Gac should be carried out.

\section{Products of Gac fruit}

Apart from its traditional uses by the locals as natural colourant, Gac is also used in commercially marketed food as food additives in medicine and cosmetics industries. Gac is used in the form of nutritional supplements such as Gac extracts in soft capsules. Fresh ripe aril is used forjuice and ice cream processing in Thailand (Kubola and Siriamornpun, 2011, Innun, 2013). Fresh gac's fruit blend consisting of honey, lemon and fresh aril are consumed in Malaysia, Indonesia, and Philipines. Commercial Gac products such as aril puree, oil, dried aril powder and juice, fruit enzyme, skin balm, soap, seed alcohol are in domestic and international markets in countries like Vietnam, China and Thailand. Gac oil and dried gac powder are marketed due to its high content of lycopene, $\beta$-carotene, and lutein. Gac aril contains oil component that plays a crucial role in the absorption of carotenes, vitamin $\mathrm{E}$ and other fat-soluble nutrients needed by the body (Chuyen et al., 2015).

\section{Conclusions}

Gac fruit (Momordica cochinchinensis Spreng.) is highly valued for its high amounts of lycopene and $\beta$-carotene, $\alpha$ tocopherol and fatty acids which has been extensively used in both nutritional and medicinal purposes. The antioxidant, antimicrobial and anticancer properties conducted in the studies evidenced the presence of bioactive compounds in Gac fruit. Although many biological properties have been reported for Gac fruit, the underlying mechanisms of action of the bioactive compounds are still lacking. Through in depth studies on this aspect of the fruit, it is hoped that it could be used as a health supplement. Currently, research are mostly focused on bioactive compounds residing in the aril and seed of Gac fruit whereas large amount of pulp and peel are discarded as waste after processing. There are enormous potential for Gac fruit pulp and peel which contained valuable sources of phytochemical which can be used in medicinal, agricultural and pharmaceutical industries.

\section{Aknowledgments}

The work was supported by Universiti Sains Malaysia TopDown Grant (1001/PBIOLOGI/8070003). Priscilla Jayanthi is the recipient of Graduate Assistant Scheme-Universiti Sains Malaysia.

\section{CONFLICT OF INTEREST}

The authors declare that they have no conflict of interest.

\section{References}

Abdulqader A, Ali F, Ismail A, Esa NM (2018) Gac fruit extracts ameliorate proliferation and modulate angiogenic markers of human retinal pigment epithelial cells under high glucose conditions. Asian Pac J Trop Biomed. 8(12):571. 
Aoki H, Kieu NT, Kuze N, Tomisaka K, Chuyen NV (2002) Carotenoid pigments in Gac fruit (Momordica cochinchinensis S.). Biosci Biotechnol Biochem. 66(11):2479-2482.

Bharathi L, Singh H, Shivashankar S, Ganeshamurthy A, Sureshkumar P (2014) Assay of nutritional composition and antioxidant activity of three dioecious (Momordica spp.) of South East Asia. Proc Natl Acad Sci India B. 84(1)31-36.

Bharathi LK, John KJ (2013) Momordica Genus in Asia-an Overview. Springer, New Delhi.

Bruno A, Durante M, Marrese PP, Migoni D, Laus MN, Pace E, Pastore D, Mita G, Piro G, Lenucci MS (2018) Shades of red: comparative study on supercritical $\mathrm{CO}_{2}$ extraction of lycopene-rich oleoresins from Gac, tomato and watermelon fruits and effect of the $\alpha$-cyclodextrin clathrated extracts on cultured lung adenocarcinoma cells' viability. J Food Compos Anal. 65: 23-32

Burke DS, Smidt CR, Vuong LT (2005) Momordica cochinchinensis S, Rosa roxburghii, wolfberry, and sea buckthorn-highly nutritional fruits supported by tradition and science. Curr Top Nutraceut R. 3(4):259.

Chao Jl, Kuo PC, Hsu TS (2004) Down-regulation of survivin in nitric oxide-induced cell growth inhibition and apoptosis of the human lung carcinoma cells. J Biol Chem. 279(19):20267-76.

Chandra S, Khan S, Avula B, Lata H, Yang MH, Elsohly MA, Khan IA (2014) Assessment of total phenolic and flavonoid content, antioxidant properties, and yield of aeroponically and conventionally grown leafy vegetables and fruit crops: A comparative study. Evid-Based Compl Alt. 2014:253875

Chuyen HV, Nguyen MH, Roach PD, Golding JB, Parks SE (2015) Gac fruit (Momordica cochinchinensis S.) a rich source of bioactive compounds and its potential health benefits. J Food Sci Technol. 50(3):567-77.

DeCosse JJ (1982) Potential for chemoprevention. Cancer. 50(11): 2550-3.

Failla ML, Chitchumroonchokchai C, Ishida BK (2008) In vitro micellarization and intestinal cell uptake of cis isomers of lycopene exceed those of all-trans lycopene. J Nutr 138(3):482-6.

Gopalakrishnan TR (2007) Vegetable crops. New India Publishing.

Gordon, DS, Rudinsky, AJ, Guillaumin, J, Parker, VJ, Creighton, KJ (2020) Vitamin in health and disease: a companion animal focus. Top Companion Anim M. 39: 100432

Guichard F, Bui DS (1941) La matiere colorante du fruit du (Momordica cochinchinnensis S.) Spr. Annales de l'ecole Superieure de Medecine et de Pharmacie de l'Indochine. 5:41-2.

Hernandez JF, Gagnon J, Chiche L, Nguyen TM, Andrieu JP, Heitz A, Trinh Hong T, Pham TT, Le Nguyen D (2000) Squash trypsin inhibitors from (Momordica cochinchinensis S.) exhibit an atypical macrocyclic structure. Biochem. 39(19):5722-30.

Huang B, Ng T, Fong W, Wan C, Yeung H (1999) Isolation of a trypsin inhibitor with deletion of $\mathrm{N}$-terminal pentapeptide from the seeds of Momordica cochinchinensis, the Chinese drug mubiezhi. Int. J. Biochem.Cell Biol. 31: 707-715.

Nguyen D (2000) Squash Trypsin Inhibitors from (Momordica cochinchinensis S.) exhibit an atypical Macrocyclic Structure. Biochem. 39(19): 5722-5730.

Innun A (2013) Antimicrobial activity of Gac fruit (Momordica cochinchinensis S.) I-SEEC 2012. Science and Engineering.1:6.

Institute of Medicine (2000). Dietary reference intakes for vitamin C, vitamin E, selenium, and carotenoids. National Academy Press, Washington DC.

Ishida BK, Turner C, Chapman MH, McKeon TA (2004) Fatty acid and carotenoid composition of Gac (Momordica cochinchinensis S.) fruit. J Agr Food Chem. 52(2):274-9.

Jung K, Chin YW, Chung YH, Park YH, Yoo H, Min DS, Lee B, Kim J (2013a) Anti-gastritis and wound healing effects of Momordicae Semen extract and its active component. Immunopharm Immunot. 35(1):126-32.

Jung K, Chin YW, Yoon KD, Chae HS, Kim CY, Yoo H, Kim J (2013b) Anti-inflammatory properties of a triterpenoidal glycoside from Momordica cochinchinensis in LPS-stimulated macrophages. Immunopharm Immunot. 35(1):8-14.

Jung K, Lee D, Yu JS, Namgung H, Kang KS, Kim KH (2016). Protective effect and mechanism of action of saponins isolated from the seeds of Gac (Momordica cochinchinensis S.) against cisplatin- induced damage in LLC-PK1 kidney cells. Bioorg Med Chem Lett. 26(5):1466-70.

Kandlakunta B, Rajendran A, Thingnganing L (2008) Carotene content of some common (cereals, pulses, vegetables, spices and condiments) and unconventional sources of plant origin. Food Chem. 106(1):85-9.

Tuyen CK, Nguyen MH, Roach PD (2010) Effects of spray drying conditions on the physicochemical and antioxidant properties of the Gac (Momordica cochinchinensis S.) fruit aril powder. J Food Eng. 98(3):385-92.

Kang JM, Kim N, Kim JH, Oh E, Lee BY, Lee BH, Shin CM, Park JH, Lee MK, Nam RH, Lee HE (2010) Effect of aging on gastric mucosal defense mechanisms: ROS, apoptosis, angiogenesis, and sensory neurons. Am J Physiol-Gastr L. 299(5):G1147-53.

Kang J, Kim N, Kim B, Kim JH, Lee BY, Park Jh, Lee Mk, Lee H, Kim JS, Jung $\mathrm{H}$, Song IS (2010) Enhancement of gastric ulcer healing and angiogenesis by Cochinchina Momordica seed extract in rats. $J$ Korean Med Sci. 25: 875-81.

Kha TC, Nguyen MH, Roach PD, Parks SE, Stathopoulos C (2013) Gac fruit: nutrient and phytochemical composition, and options for processing. Food Rev Int. 29(1):92-106.

Kha TC, Nguyen MH, Roach PD , Stathopoulos CE (2014) Microencapsulation of Gac oil by spray drying: optimization of wall material concentration and oil load using response surface methodology. Dry Technol. 32: 385-397.

Kubola J, Meeso N, Siriamornpun S (2013) Lycopene and beta carotene concentration in aril oil of Gac (Momordica cochinchinensis S.) as influenced by aril-drying process and solvents extraction. Food Res Int. 50(2):664-9.

Kubola J, Siriamornpun S (2011) Phytochemicals and antioxidant activity of different fruit fractions (peel, pulp, aril and seed) of Thai Gac (Momordica cochinchinensis S.). Food Chem. 127(3):1138-45.

Kuhnlein HV (2004) Karat, pulque, and Gac: three shining stars in the traditional food galaxy. Nutr Rev. 62(11):439-42.

Le A, Huynh T, Parks S, Nguyen M, Roach P (2018) Bioactive composition, antioxidant activity, and anticancer potential of freeze-dried extracts from defatted Gac (Momordica cochinchinensis S.) seeds. Medicines. 5(3):104.

Lee SH, Jeong YS, Song J, Hwang KA, Noh GM, Hwang IG (2017) Phenolic acid, carotenoid composition, and antioxidant activity of bitter melon (Momordica charantia L.) at different maturation stages. Int J Food Prop. 20:S3078-S3087.

Leevutinun P, Krisadaphong P, Petsom A (2015) Clinical evaluation of Gac extract (Momordica cochinchinensis) in an antiwrinkle cream formulation. J Cosmet Sci. 6: 175-87.

Lim TK (2012) Momordica cochinchinensis edible medicinal and nonmedicinal plants .Springer, Dordrecht, the Netherlands.369-380.

Liu HR, Meng LY, Lin ZY, Shen Y, Yu YQ, Zhu YZ (2012) Cochinchina momordica seed extract induces apoptosis and cell cycle arrest in human gastric cancer cells via PARP and p53 signal pathways. Nutr Cancer. 64(7):1070-7.

Lopez-Huertas E (2010) Health effects of oleic acid and long chain omega-3 fatty acids EPA and DHA enriched milks a review of intervention studies. Pharmacol Res. 61(3):200-7.

Lu R, Dan H, Wu R, Meng W, Liu N, Jin X, Zhou M, Zeng X, Zhou G, Chen $Q$ (2011) Lycopene: features and potential significance in the oral cancer and precancerous lesions. J Oral Pathol Med. 40(5):361-8.

Mai HC, Truong V, Debaste F (2013a) Optimization of enzyme-aided extraction of oil rich in carotenoids from Gac fruit (Momordica cochinchinensis S.). Food Technol Biotechnol. 51(4):488-99.

Mai HC, Truong V, Haut B, Debaste F (2013b) Impact of limited drying on (Momordica cochinchinensis S.) aril carotenoids content and antioxidant activity. J Food Eng.118(4):358-64.

Mazzio E, Georges B, McTier O, Soliman KF. Neurotrophic Effects of Mu Bie Zi (2015) (Momordica cochinchinensis) seed elucidated by high-throughput screening of natural products for NGF mimetic effects in PC-12 cells. Neurochem res. 40(10):2102-12.

Mazzio E, Badisa R, Eyunni S, Ablordeppey S, George B, Soliman KF (2018) Bioactivity-uided isolation of neuritogenic factor from the seeds of the Gac plant (Momordica cochinchinensis). Evid Based Complement Alternat Med. Article ID 8953958 
Minh NP, Dao DT (2013) Investigation different pretreatment methods and ratio of carrier materials to maintain carotenoids in Gac (Momordica cochinchinensis S.) powder in drying process. Int J Sci Eng Technol. 2(12):360-71.

Muller-Maatsch J, Sprenger J, Hempel J, Kreiser F, Carle R, Schweiggert RM (2017) Carotenoids from Gac fruit aril (Momordica cochinchinensis [Lour.] Spreng.) are more bioaccessible than those from carrot root and tomato fruit. Food Res Int. 99: 928-935.

Natnoi S, Pirak T (2019) Effect of ultrasonic-assisted extraction on the properties, antioxidant and inflammatory activities of carotenoids from Gac (Momordica cochinchinensis) fruit pericarp. Cogent Food Agric.1696512.

Nhung DT, Bung PN, Ha NT, Phong TK (2010) Changes in lycopene and beta carotene contents in aril and oil of Gac fruit during storage. Food Chem. 121(2):326-31.

Parks SE, Murray CT, Gale DL, Al-Khawaldeh B, Spohr L (2013) Propagation and production of Gac (Momordica cochinchinensis S.), a greenhouse case study. Exp Agr. 49(2):234-43.

Petchsak P, Sripanidkulchai B (2015) (Momordica cochinchinensis S.) aril extract induced apoptosis in human MCF-7 breast cancer cells. Asian Pac J Cancer Prev.16(13):5507-13.

Phan-Thi H, Waché $Y$ (2014) Isomerization and increase in the antioxidant properties of lycopene from (Momordica cochinchinensis S.) (Gac) by moderate heat treatment with UV-Vis spectra as a marker. Food Chem.156:58-63.

Poudyal H, Panchal SK, Diwan V, Brown L (2011) Omega-3 fatty acids and metabolic syndrome: effects and emerging mechanisms of action. Prog Lipid Res 50(4):372-87.

Putta S, kumar Kilari E, Sastry N (2014) Evaluation of phytochemicals and antimicrobial activity of (Momordica cochinchinenesis S.) against some pathogenic microorganisms. J of Glob Tren in Pharm Sci. 5(4): $2181-2185$

Reboul E (2019) Mechanisms of carotenoid intestinal absorption: where do we stand? Nutrients. 11: 838.

Reungpatthanaphong $S$, Kirdin $T$, Chinnawong $M$, Bamrungchai $M$, Reungpatthanaphong P (2018). Anti-oxidant activity of accelerated solvent extraction from different fractions of Thai Gac fruit (Momordica cochinchinensis S.). Thai J of Pharm Sci. 42:3740.

Rodriguez- Amaya DB (2015) Food carotenoids : Chemistry, Biology and Technology, John Wiley \& Sons.

Rodriguez-Leyva D, Bassett CM, McCullough R, Pierce GN (2010) The cardiovascular effects of flaxseed and its omega-3 fatty acid, alpha-linolenic acid. Can J Cardiol 26(9):489-96.

Sarmah P, Dutta S, Sarma A (2018) Phyto-chemical properties of Momordica cochinchinensis

Spreng : an underutilised wild edible fruit from Cachar Hills, Assam. Agrofor Syst. 92: 85-59.

Seino $Y$, Miki T, Kiyonari H, Abe T, Fujimoto W, Kimura K, Takeuchi A, Takahashi Y, Oiso Y, Iwanga T, Seino S (2008) Isx participates in the maintenance of vitamin $A$ metabolism by regulation of betacarotene 15, 15'-monooxygenase (Bcmo1) expression. J Bio Chem. 284: 4905-11.

Shukla Y, George J (2011) Combinatorial strategies employing nutraceuticals for cancer development. Ann N Y Acad Sci. 1229(1):162-75.

Sowjanya K, Swathi S, Ramyasree B, Saimounika A (2015) Evaluation Of antiulcer activity Of (Momordica ochinchinensis S.) fruits. Int J Pharmacol. 6(2):62-65.

Sukhorum W, Sampannang A, Sripanidkulchai B, lamsaard S (2016) Momordica cochinchinensis (L.) Spreng aril extract prevents adverse reproductive parameters of male rats induced with valproic acid. Int J Morphol. 34(3):870-6.

Tien PG, Kayama F, Konishi F, Tamemoto H, Kasono K, Hung NT, Kuroki M, Ishikawa SE, Van CN, Kawakami M (2015) Inhibition of tumor growth and angiogenesis by water extract of Gac fruit ( Momordica cochinchinensis Spreng). Int J Oncol. 26 : 881-9

Tinrat S (2014) Comparison of antioxidant and antimicrobial activities of unripe and ripe fruit extracts of (Momordica cochinchinensis S.) (Gac fruit). Int J Pharm Sci Rev Res. 28 (1):7582.
Tinrat S, Akkarachaneeyakorn S, Singhapol C (2014). Evaluation of antioxidant and antimicrobial activities of (Momordica cochinchinensis S.) (Gac fruit) ethanolic extract. Int J Pharm Sci Rev Res. 5(8):3163.

Tinrat S, Asna MS (2016) Antimicrobial and synergistic efects with antibiotics of (Momordica cochinchinensis S.) (Gac fruit) aril against pathogenic bacteria. Int J Pharm Sci Rev Res. 39(2): 286294.

Tran XT, Parks SE, Nguyen MH, Roach PD, Kha TC (2017). Changes in physicochemical properties of Gac fruit ('Momordica cochinchinensis S.) during storage. Aust J Crop Sci. 11(4): 447.

Tran XT, Parks SE, Roach PD, Golding JB, Nguyen MH (2016). Effects of maturity on physicochemical properties of $\mathrm{Gac}$ fruit (Momordica cochinchinensis S.). Food Sci Nutr. 4(2):305-314.

Tuyen CK, Nguyen MH, Roach PD, Stathopoulos CE (2013) Effects of Gac aril microwave processing conditions on oil extraction efficiency, and $\beta$-carotene and lycopene contents. J Food Eng. (4): 486-491.

Vuong LT, King JC (2003) A method of preserving and testing the acceptability of Gac fruit oil, a good source of $\beta$-carotene and essential fatty acids. Food Nutr Bull. (2), 224-230.

Vuong LT (2000). Underutilized $\beta$-carotene-rich crops of Vietnam. Food Nutr Bull. 21(2): 173-181.

Vuong LT, Dueker SR, Murphy SP (2002) Plasma $\beta$-carotene and retinol concentrations of children increase after a 30- $d$ supplementation with the fruit (Momordica cochinchinensis S.) (Gac). Am J Clin Nutr. (5): 872-879.

Vuong LT, Franke AA, Custer LJ, Murphy SP (2006) (Momordica cochinchinensis S.) (Gac) fruit carotenoids reevaluated. J Food Compos Anal. (6-7) :664-668.

Wang M, Zhan Z, Xiong Y, Zhang Y, Li X (2019) Cytotoxic and antiinflammatory constituents from Momordica cochinchinensis seeds. Fitoterapia. 139:104360.

West CE, Poortvliet EJ (1993) The carotenoid content of foods with special reference to developing countries. USAID, VITAL International Science and Technology Institute, Washington, DC.

Wimalasiri D, Piva T, Huynh T (2016) Diversity in nutrition and bioactivity of Momordica cochinchinensis. Int J Adv Sci Eng Inf Technol. 6: 378-380.

Win S, Mejunpet N, Buanong M, Kanlayanarat S, Wongs-Aree C (2015a) Postharvest quality alteration of Gac fruit harvested at different maturities and coated with chitosan. Int Food Res J. 22(6):2219.

Win S, Buanong M, Kanlayanarat S, Wongs-Aree C (2015b) Response of Gac fruit (Momordica cochinchinensis Spreng) to postharvest treatments with storage temperature and 1-MCP. Int Food Res J. 22(1):178.

Wong RC, Fong WP, Ng TB (2004) Multiple trypsin inhibitors from (Momordica cochinchinensis S.) seeds, the Chinese drug mubiezhi. Peptides. 25(2):163-169.

Xiao C, Hu S, Rajput ZI (2007)Adjuvant effect of an extract from (Cochinchina momordica S.) seeds on the immune responses to ovalbumin in mice. Front Agric China. 1:90-95.

Yeum KJ, Russell RM (2002) Carotenoid bioavailability and bioconversion. Annu Rev Nutr. 22(1): 483-504.

Yu JS, Roh HS, Lee S, Jung K, Baek KH, Kim KH (2017) Antiproliferative effect of (Momordica cochinchinensis S.) seeds on human lung cancer cells and isolation of the major constituents. Rev Bras Farmacogn. 27(3)L329-333.

Zheng L, Zhang YM, Zhan YZ, Liu CX (2014) (Momordica cochinchinensis $S$.) seed extracts suppress migration and invasion of human breast cancer ZR-75-30 cells via down-regulating MMP2 and MMP-9. Asian Pac J Cancer Prev. 15(3): 1105-1110.

Zheng L, Zhang Y, Liu Y, Yang XO, Zhan Y (2015) (Momordica cochinchinensis $\mathrm{S}$.) seed extract suppresses breast cancer growth by inducing cell cycle arrest and apoptosis. Mol Med Rep. 12(4):6300-6310. 